\title{
МЕТОДОЛОГІЧНІ АСПЕКТИ ФОРМУВАННЯ МОВЛЕННСВОЇ КУЛЬТУРИ СТУДЕНТІВ-ПЕРШОКУРСНИКІВ, МАЙБУТНІХ АКТОРІВ
}

\begin{abstract}
Стаття присвячена висвітленню методологічних аспектів роботи зі студентами-першокурсниками на заняттях зі сиенічної мови, вихованню фахівиів-професіоналів. Досліджено проблему переходу студента від побутового мовлення до виразного звучання акторського голосу, а також розглянуто різні технічні практики, що розвивають голосо-мовленнєвий апарат.
\end{abstract}

Ключові слова: мовний тренаж, сиенічна мова, методологія.

Статья посвящена освещению методологических аспектов работы со студентами-первокурсниками на занятиях по сиенической речи, воспитанию специалиста-профессионала. Исследована проблема перехода студента от бытовой речи к выразительному звучанию актерского голоса, а также рассмотрены различные технические практики, развивающие голосо-речевой аппарат.

Ключевые слова: речевой тренаж, сиеническая речь, методология.

The article is devoted to the highlighting of the methodological aspects of work with first year students in the stage language lessons, studying of a specialist-professional. The problem of student transition from household speech to the expressive sound of an actor's voice is examined, as well as various technical practices developing the voice-speech device are considered. Key words: language training, stage language, methodology.

Key words: language training, stage language, methodology.

Метою статті є вироблення системи теоретико-практичних знань, практичних вмінь і навичок володіння голосово-мовленнєвим апаратом, засвоєння елементів виконавського мистецтва, удосконалення культури мови майбутнього професіонального актора.

Методологія дослідження полягає у застосуванні аналітичного, структурного, функціонального методів дослідження під час вивчення особливостей навчальної діяльності студентів, що готуються до професійної сцени.

Наукова новизна дослідження визначається тим, що ці методологічні розвідки сприятимуть вирішенню конкретних практичних завдань у професійному навчанні й сприятимуть усуненню наявних мовленнєвих недоліків студентів-першокурсників.

Висновки: Методологія мовного тренажу першокурсників - це складний динамічний процес, заснований на підборі різних індивідуальних методів та прийомів, спрямованих на розвиток виразності акторського слова, а також задля подолання мовних дефектів.

Ключові слова: викладач, студент-першокурсник, методологія, сценічна мова, мовний тренаж.

Методологія розвитку культури сучасної сценічної мови - проблема актуальна, адже студент-першокурсник, що приходить здобувати професію актора, повинен збагачувати й розширювати свій культурний і духовний рівень насамперед через набуття професійних навичок.

У формуванні особистості студента-першокурсника i «переформатування» його в професіонального актора, є два головних аспекти - професійний і культурний. Заняття зі сценічної мови покликані давати не лише системні знання, а й формувати професіональну особистість майбутнього актора: інтелігентної людини із творчим та гуманним способом світобачення, світосприймання. 
Як справедливо зазначає А. В. Гладишева: «У сьогоденній театральній практиці, на жаль, нерідко порушуються усталені літературні норми, трапляються випадки недбалого ставлення артистів i, звичайно, режисерів до сценічної мови, нехтування кращими традиціями сценічного слова українського театру» [3]. Тобто слід на самому початку роботи 3 першокурсниками формувати навички сценічного мовлення, які б домінували в акторській майстерності. Як відомо, актор має стати носієм справжньої культури мови, хранителем унікальності, але хранителем особливим, що iii розвиває, збагачує, відшліфовує культуру українського театру.

Результат освіти визначають надбані компетенції, якими повинні оволодіти випускники до моменту закінчення курсу «Сценічна мова». Основною метою сучасної вищої освіти є підготовка високопрофесіонального, конкурентоспроможного і затребуваного на ринку праці фахівця і водночас формування всебічно розвиненої особистості. Педагогічна література останніх десятиліть спирається на дослідження таких вчених, як О. Ласкава, А. Гладишева, Т. Запорожець та інші. Попри досить значні наукові доробки цих та багатьох інших дослідників, проблема залишається актуальною. Аналіз різних підходів дає змогу зробити висновок про різноманітність технік і підходів до викладання, кожна $з$ яких має право на існування й водночас потребує доповнення іншою. Однак сучасна методологія сценічної мови прагне до цілісного формування конкретних навичок, сформованих не як формальне поєднання різнопланових підходів, а як залучення надбань, що відкривають ті чи інші грані особистості як цілісної істоти [1]. У прагненні до професійної компетентності, молодий актор повинен синтезувати низку властивостей.

Сценічна мова - один 3 ключових засобів втілення драматичного твору, передачі головної ідеї, що іiі закладає автор у створений образ. Якщо актор бездоганно володіє сценічною мовою, то він точно і правдиво передає образ персонажа, розкриваючи його внутрішній світ, соціальний, побутовий, національний та психологічний характер персонажа.

Техніка сценічної мови - провідний елемент акторської майстерності, основними ознаками якої є звучність (резонатори); гнучкість, об’єм голосу (регістри); рівень розвитку дихання, чіткість і ясність вимови (дикція), інтонаційна виразність. Це один з основних професійних засобів виразності актора.
Комплексне навчання студента-першокурсника передбачає переламні зміни насамперед у мовленні: від спрощеного побутового мовлення, притаманного більшості абітурієнтів, до яскравого й виразного сценічного звучання акторського голосу. Таке навчання стосується ряду ключових аспектів, зорієнтованих на формування пластичної свободи, розвиток рухливості й еластичності голосового та дихального апаратів, вдосконалення мовленнєвого слуху, постановки голосу.

На сцені співіснують у природному поєднанні різні функціональні стилі мовлення - діловий, художній та розмовний. Умови функціонування мови в театрі настільки підпорядковані вимогам сценічної практики, що слід говорити про окремий, неповторний стиль сценічного мовлення. «Багатьма людьми культура української усної літературної мови (iї орфоепії, мелодики) пізнавалися саме через цей театр (театр корифеїв)», - відзначає І. К. Білодід [1].

Професіональний голос відрізняється витривалістю різноманітного мовленнєвого навантаження, широтою діапазону, дикційною чіткістю і виразністю, вправним володінням темпоритмами мовлення та силою звучання. 3 приводу якості деяких розмовних побутових голосів режисер, актор і педагог М. К. Вороний, зокрема, зауважував, що вони бувають навіть «невдячні, з нечистим звуком глухі, хрипкі, верескливі. Здебільшого сі вади не органічні, а набуті, здавна засвоєні» [2, 49]. Майже $40 \%$ інформації передається саме через голос, тон і тембр (від фр. Timbre - якість, окраса звуку). Актор тримає увагу глядача не лише змістом тексту, а й своєрідністю забарвлення звуку - тембром голосу та його енергетикою. Ця енергетика звучання голосу безпосередньо залежить від конкретної дії, що за допомогою слова твориться в результаті внутрішнього процесу переживання певних обставин у конкретній ситуації ролі. Розглядаючи варіативність спектра тембрального забарвлення акторського голосу під час роботи над роллю, не можна не згадати слова актора і театрального педагога Л. Ф. Макар'єва: «Голос людини - це його біографія. Він виховується разом з людиною. Голос - це звук, і тембр, і глибина, i “гора”, i “низ”, і почуття, і думка. Власне кажучи, голос - це “Я”, яким мене створила природа, довкілля і я сам. "Розмовний голос" - це будівельний матеріал, 3 якого будується сценічна дія. Це - складова частина, але вирішальна у створенні самої “сценічної людини”». Формування звуку - мови персонажа - $є$ завдання роботи над роллю, сторона утворення сценічної людини - творче завдання в 
роботі над образом» $[5,15]$. Не варто забувати про те, що в театрі ми не лише дивимося виставу, а й слухаємо, тому можна розглядати голос актора як «останній етап перед сприйняттям тексту вистави глядачем» $[4,27]$. Слова «постановка голосу» означають: за допомогою упорядкованого фонаційного дихання опанувати технічними прийомами голосоведення та резонування, використати, посилити резонаторно-енергетичне й розширити діапазонне звучання голосу, покращити його рухливість, мелодійність, витривалість. М. К. Вороний «правильною постановкою голосу» називав таку, «при якій голос має: милозвучність, повноту, силу, витриманість і гнучкість» $[2,75]$. Слід зауважити, що поняття «постановка голосу» прийшло в театральну школу $з$ вокальної педагогіки, тож має на увазі специфічні навички звучання, далекі від природного звучання. «... Нелегко погодитися 3 установкою, що мовний голос можна поставити pa3 і назавжди. Це неможливо хоча б в силу біологічних, фізіологічних і психічних факторів, що впливають на роботу мовленнєвого апарату в моменти фонації», - пише він $[2,75]$.

Завдання, яке ставиться при навчанні майбутніх акторів техніки мови - це виявлення, розвиток і вдосконалення голосових даних студентів-першокурсників, якими вони володіють. Розкрити їх індивідуальні голоси і навчити вільно і легко користуватися ними. У результаті роботи над розкриттям потенціалу індивідуальних вільних голосів, професіонально придатних для роботи як на театральній сцені, так і в кіно, слід звернути увагу на формування таких якісних характеристик першокурсників, як:

- свобода м'язів - це розвиток м'язів, що беруть участь у дихальному процесі, фонації й дикції, при якому відсутні напруга й фізичні зажими;

- активність м'язів - стан голосових зв'язок, м'язів гортані, глотки і всього мовного апарату, що не допускає млявості;

- витривалість голосу - такий рівень володіння своїм мовним апаратом, при якому не відбувається стомлюваності м'язів, не відчувається погіршення якості звучання;

- рухливість тембру голосу - вміння керувати різними якостями звучань голосу, залучати в роботі над роллю емоційні забарвлення голосу, різні обертони;

- об'ємність голосу - властивість глибини, «оксамитовості», м’якості, округлості. Безбарвні, плоскі голоси недопустимі для актора-професіонала. Хоча, можлива певна своєрідність голосу, вироблена спеціально;
- діапазон висоти звуку - вміння використовувати максимальний тоновий обсяг мовленнєвого голосу, від найнижчого до найвищого звуку;

- діапазон динаміки - вміння користуватися голосом за умови різної подачі і сили звуку, без втрати тембрального забарвлення голосу.

Слід зазначити, що всі ці якісні характеристики голосу не існують ізольовано одна від одної, тобто займатися розвитком їх потрібно в синтетичному тренінгу, де одна вправа випливає з іншої. Іншими словами, займатися розвитком голосу в першокурсників потрібно в рамках методологічно правильного системного тренінгу.

Насамперед, треба впевнитися, що студенти мають необхідний рівень мотивації для того, аби опанувати технікою мовлення. Потрібно стежити за тим, щоб вдих робився саме носом, оскільки при ротовому диханні велика ймовірність травмування холодним повітрям голосових складок. У практичних заняттях зі сценічної мови, а саме в тренінгах із постановки голосового апарату, завданням педагога $\epsilon$ виявлення та закріплення індивідуального звучання кожного окремого студента. На першому етапі роботи слід провести діагностику голосів першокурсників, для того щоб виявити проблеми кожного окремого голосу, зрозуміти, у кого з майбутніх акторів завищений голос, у кого затиснуті щелепні м'язи, у кого голос ще «не визначений». Це потрібно для того, щоб правильно розподілити навантаження на різні групи м'язів кожного студента. Зазвичай проблеми першокурсників дуже схожі, тому досить швидко вибудовується загальна для всіх система тренінгу. Найпершою проблемою, яка притаманна для першокурсників, $є$ так звана затиснута щелепа. Пропонуємо такі вправи: кладемо до рота чотири пальці, тримаючи їх у такому положенні кілька секунд і звертаючи увагу на те, на які м'язи припадає максимальне навантаження. Вийняти пальці, закрити рот. Проаналізувати свої відчуття. Кілька разів відкрити рот на таку ж величину, не вдаючись до допомоги рук. Максимально затиснути, а потім розслабити щелепи. Повторити декілька разів, аналізуючи відчуття. Закріпити стан свободи щелепи після затиску. О. Ласкава пропонує використовувати такий професійний термін, як «точка свободи» $[5,7]$. Цей термін застосовується до всіх груп м'язів, від лицьових і аж до м'язів на пальцях ніг. Щоб зрозуміти природу цього явища, треба міцно стиснути обидві кисті рук і з усієї сили натиснути одним кулаком на інший. Затримати руки в такому стані на 10 секунд, скинути напругу, розслабити руки. Митте- 
вий стан розслабленості ми і називаємо «точкою свободи».

Як показали перші заняття, студенти не завжди вміють контролювати одночасно всі групи м'язів. Дуже часто, займаючись, наприклад, розслабленням м'язів черевного преса, вони затискають шийні м'язи і т. п. Завдання педагога полягає в тому, щоб не пропускати такі моменти і звертати увагу студентів на ці зажими. Студенти повинні ще сильніше затиснути вже затиснуту групу м'язів, щоб потім різко розслабити іiі, після чого звернути свою увагу на ту вправу, яку вони робили до цього. Слід привчати майбутніх акторів до самостійного контролю за відчуттями.

Одним із чинників формування правильного звучання голосу є опора на реберно-діафрагмальне дихання. У студентів-дівчат зазвичай переважає у реальному житті грудне дихання, а в хлопців - черевне. Завдання - 3 перших занять націлити роботу на розвиток діафрагмально-реберного дихання. Це надає голосу обертонів, міцності звучання, резонування. Не слід зневажати вправами, що розвивають дихання «на опорі», тобто зміцнюють посил звуку і його чутність. Одна із проблем, 3 якими приходять першокурсники, - «говорити в ніс». Щоб позбутися такої мовної проблеми, потрібно розпрацювати резонатори (головний i грудний). Правильно розроблений головний резонатор дає польотність голосу. Грудний - силу голосу. Пропонується виконання такого комплексу вправ: мі-ме-ма-мо-му-мим. Уявляємо, що у нас в «тім'ячку» антенка - зв'язок із космосом - і намагаємось посилати звук вгору, округливши гортань, зробити «купол», зуби не зціплені, «мугикаємо» цю вправу декілька разів [5, 7].

На грудний резонатор розробляємо таку вправу: «мі-ме-ма-мо-му-ми-мам-меду-нам». На одній ноті проговорити, ніби співаючи, низько, щелепа не затискається, відкривати рот, говорити максимально низько, зв'язки не напружувати $[5,7]$.

Ця вправа допомагає налаштувати організм студента до подальших вправ на резонування, регістри та артикуляцію. Вібрації, що йдуть по всьому тілу, під час роботи над вправою, «вмикають» організм. Потрібно робити вправу так, щоб усе тіло було повністю розслабленим, окрім ніг. Треба стежити за свободою тіла і свободою щелепи: зуби розціплені, губи затиснуті.

Пропонується цикл вправ на «народження звуку». Початкова позиція: виконується вправа стоячи прямо, ноги на ширині плечей, стопи розташовані паралельно. Пропонується розслабити корпус, тобто всі м'язи, крім м'язів ніг. Опуска- ється тіло вперед. Ноги прямі і в міру напружені. Слід уявити, що ми знаходимося в лазні з дуже приємним легким паром. Перевіряємо, чи достатньо розслаблені руки, м'язи шиї. Уявляємо, що руки перетворилися у віники, а потім починаємо поплескувати себе абсолютно розслабленими кистями рук спочатку по ногах, потім по животу, боках, шиї, плечах, руках, потім по спині, не чіпаючи нирки. Паримося ретельно, не пропускаючи жодного сантиметра тіла. Під час вправи артикулюємо звук «М». Обов'язково перевіряємо незатиснутість шийних м'язів.

Найпоширеніші помилки при виконанні цієї вправи - це затиснута щелепа і здавлена гортань. Щоб уникнути цього, потрібно постійно нагадувати студентам про те, що при виконанні цієї вправи мають бути зімкнуті губи і розімкнуті зуби. Можна також запропонувати їм зробити напівпозіхання. О. Ласкава таку поставу мовного апарату назвала «яблуко в роті» $[5,34]$. Під час вправ на розвиток звуків, слід акцентувати увагу на будову органів, що беруть участь у мовному процесі. У будь-якій спеціальній літературі $є$ докладний опис цих органів і принципів їх роботи. Але такі знання фізіологічної будови всіх мовленнєво-голосових органів - необхідна умова для якісної постановки сценічної мови. Студентам потрібно детально розповісти не лише про будову легенів, гортані, трахеї, рота і носа, а й про анатомічну будову людини в цілому. У тренінгах використовуємо вправи з популярних сьогодні східних практик, зокрема 3 йоги, а також вправи 3 практик різних дихальних і голосових шкіл, автори яких теж базувалися на практиках Сходу. Використовуючи такі методики, переконалися, що студенти повинні бути добре поінформовані про те, яку мету ми перед собою ставимо. Їм слід детально знати, як влаштований наш організм. I якщо педагог пропонує своїм подихом прогріти той чи інший внутрішній орган, то студент повинен, як мінімум, знати, де той орган розміщений.

Вправи, спрямовані на тренування вдиху. Це дуже важливо, привчити саме довільно навчитися вдихати і видихати, адже дихання - це основа. Від правильного вдиху і видиху формується правильне голосоведення і мовленнєві норми.

Стати прямо, поставити ноги на ширину плечей. Покласти ліву руку на живіт. Уявити, що в правій руці ми тримаємо рукавичку, яку дуже різким рухом відкидаємо від себе, видихаючи зі звуком «Т». Після шістнадцяти рухів починаємо відкидати рукавичку подвійним рухом - «Т-Т», після того знову шістнадцять рухів - потрійним 
«Т-Т-Т», тоді слід виконувати вправу в зворотному порядку. Лівою рукою контролюємо рух діафрагми. 3 кожним видихом має відбуватися різке скорочення м'язів. Вдих робиться автоматично.

Вправа для тренування правильного видиху. Перший етап виконання вправи називається «Неслухняна свічка». Стати прямо, ноги на ширині плечей. Зробити глибокий вдих i, уявивши перед собою свічку, спокійним, довгим видихом на звук «П» намагатися утримати іiї полум'я в горизонтальному положенні. Видихати потрібно повільно й при цьому старатися робити це максимально довго.

На другому етапі виконання вправи «Свічка», потрібно повільно задути свічку, імітуючи вимову звука «П-п-п». Ця вправа відрізняється від першої швидкістю видиху.

Третій етап - «загасити свічку». Швидким, різким видихом задути свічку. Кожну вправу потрібно повторити декілька разів.

На жаль, сьогодні навіть професіональні актори не завжди дотримуються єдиних мовно-художніх принципів, які визначають загальний рівень і критерії високої культури сценічної мови. Часом строкатість, безбарвність, невиразність акторського слова, діалектизми, неправильні наголоси, взагалі порушення вимови звуків справляють враження мовного нігілізму. Особливу увагу треба звернути на дотримання орфоепічних норм, на такі явища, як русизми або «діалектна говірка». У студентів-першокурсників «мовний апарат» не пристосований до сценічної, нової для них мови. Завданням початкових занять $€$ викорінювання вказаних звичок. Допомагають вправи: взяти до рота корок, із корком у роті повільно вимовляти скоромовки, при цьому технічно зберігаючи правильну позицію. Обов'язковою умовою у постановці голосоведіння $є$ впровадження і неухильне дотримання так званого мовного режиму - розмовляти сценіч- ною правильною мовою як під час занять, так i на перервах, у вільному спілкуванні. Це особливо важливо для російськомовних студентів, адже їм треба навчитися поєднувати мисленнєво-мовленнєві процеси, тобто думати українською мовою, вільно добираючи слова. Потрібно навчити контролювати вимову в побуті, виробляти свідоме ставлення до сценічної мови, аби уникнути явища «забуття теорії» з порогом навчального закладу, натомість спонукати розмовляти чітко, виразно і правильно й у побуті. Таким чином, методологія мовного тренажу першокурсників - це складний динамічний процес, заснований на підбиранні різних індивідуальних методів та прийомів спрямованих на розвиток виразності акторського слова, а також задля подолання мовних дефектів.

\section{Джерела та література}

1. Бех І. Д. Психологічні джерела виховної майстерності : навч. посіб. / І. Д. Бех. - К. : Академвидав, 2009. - 248 с.

2. Вороний М. К. Драма і театр / М. К. Вороний. - К. : Мистецтво, 1989. - $408 \mathrm{c}$.

3. Гладишева О. А. Слово в театрі, 2006. (Електронний ресурс). Джерело доступу: http://kulturamovy.univ.kiev.ua/ KM/pdfs/Magazine22-20.pdf.

4. Дятчук В. В., Барабан Л. І. Український тлумачний словник театральної лексики / В. В. Дятчук, Л. І. Барабан. 2-ге вид., переробл. і допов. - К. : Вид. центр «Просвіта», 2002. - 192 с. : іл.

5. Ласкавая Е. В. Сценическая речь / Е. В. Ласкавая. - М. : ВЦХТ («Я вхожу в мир искусств»), 2005. -144 с.

\section{Referens:}

1. Bekh, I. D. (2009). Psychological sources of educational skill : Teach. manual. - Kyiv : Akademvidav, 248 [in Ukranian].

2. Voronyi, M. K. (1989). Drama and theater. - Kyiv : Art, 408 [in Ukranian].

3. Gladysheva, O. A. (2006). Word in the theater. - URL: http:// kulturamovy.univ.kiev.ua/KM/pdfs/Magazine22-20.pdf. [in Ukranian].

4. Dyatchuk, V. V., Baraban, L. I. (2002). Ukrainian Explanatory Dictionary of Theater Linguistics. - 2nd form., reworked and listens. - Kyiv : Vyd. center «Prosvita», 192 [in Ukranian].

5. Laskavaya, E. V. (2005). Stage speech. - Moscow : VTSKHT («I am entering the world of arts»), 144 [in Russian]. 